\title{
EGY SZOKATLAN VITA
}

\section{AN UNUSUAL DISCUSSION OF A MONOGRAPHY}

\author{
Dénes Iván Zoltán \\ DSC, az Academia Europaea választott tagja, a történelemtudományok doktora, \\ nyugalmazott egyetemi tanár, kutatócsoport-vezető, Marczali Henrik Kutatócsoport, OR-ZSE \\ denes.ivan.zoltan@gmail.com
}

\section{ÖSSZEFOGLALÁS}

Szabad politikatörténeti nagymonográfiája megírása előtt Molnár Erik (Szabó Ervint követve) felülírta a népi=haladó, népi=nemzeti, nemzeti, tehát haladó - Szűcs Jenő által feltárt - szillogizmusát, és Révai József tételét a kettős lelkű középnemesség polgári funkciójáról. Előfeltevése, a haladó, tehát nem nemzeti alapján a Habsburg-abszolutizmust és birodalmat haladónak, a magyar nemességet feudálisnak, a rendi nemesi függetlenségi harcokat szeparatistának és reakciósnak minősítette. Molnár Erik és a nézetei körül kialakult vita számos tabut tört meg, ami megnyitotta az utat a korábbi sémáktól mentes kutatások előtt. Molnár Erik merev antinacionalista történelemfelfogásával - amelyet (a balti szovjetköztársaságokban alkalmazott nomenklatúra-csere és antinacionalista kampány után) az 56-os forradalom örökségével szemben fogalmazott újra, és emelhetett a Kádár-rendszer történettudományi kánonjává - ugyanakkor új tabukat hozott létre. Ezek közé tartozott a nemzeti önrendelkezés, a nemzetépités és a nemzeti függetlenség, amelyeket nem önértéknek, hanem a társadalmi haladás eszközének, többnyire akadályának, hátráltatójának minősített. Szabad György 1964-ben írt, és 1967-ben megjelent könyvét, amelyben mind a Révai-féle, mind a Molnár Erik-féle értelmezéstől független mondanivalót fejtett ki, ötven éve komoly, drámai vitában védte meg. Tanulmányomban arra keresem a választ, hogy múve akadémiai védése során kik, milyen álláspontokat foglaltak el, s azt hogyan tették. Arra, hogy álláspontjuk kifejtése során milyen értelmezési kereteket alkalmaztak, s azt milyen kánonok alapján tették.

\section{ABSTRACT}

The international political historical context of the discussion reconstructed, analysed and interpreted in this essay was the Marxist canon, the interpretative framework of the modern Hungarian history based upon the French 1848 political revolutions and its aftermath in 1849-51 going back to Karl Marx's The Eighteenth Brumaire of Louis Bonaparte on the one hand and the two communist images of Lajos Kossuth as the defender of the class privileges (Ervin Szabó and Erik Molnár), and the inconsistent revolutionary (József Révai). The main point of the unusual discussion of The Crossroads of Revolution and Compromise, 1860-61 was the fact, the process and the varieties of breaking away from the canonised interpretative schemes. 
Kulcsszavak: indoktrináció, értelmezési keret, megbélyegzés, mesterelbeszélés

Keywords: indoctrination, interpretative framework, stigmatization, master-narrative

\section{BEVEZETÉS}

Több mint ötven évvel ezelőtt, 1969. október 27-28-án a Magyar Tudományos Akadémián egy akadémiai doktori értekezés a pártállami keretek között szokatlan, sőt példátlan vitája zajlott le. Olyan, amely ugyancsak feszegette a pártállami kereteket. E szokatlan és példátlan vita álláspontjait, az álláspontok ütközéseit, előfeltevéseit és értelmezési kereteit fogom rekonstruálni, elemezni és értelmezni, hogy levonhassam a tanulságait.

\section{AZ AKADÉMIAI DOKTORI VÉDÉS KEZDETE}

A jegyzőkönyv később közreadott kivonata szabályos, megszokott, rituális eseményt sejtetett. Holott a védés szokatlan, sőt az akadémiai doktori védések sorában egyenesen példátlan volt. Szokatlan volt, mert Szabad György már megjelent vaskos, 644 oldalas nagymonográfiáját, a Forradalom és kiegyezés válaszútján (1860-61) címü könyvét nyújtotta be értekezésként. Példátlan pedig azért volt, mert a jegyzőkönyv tanúsága szerint a védés két napig, tíz órán keresztül tartott. Ugyanis Lukács Lajos, a történelemtudományok kandidátusa, számos vitában Szabad ellenfele, obstrukcióval felérő hozzászólalásával hosszú órákra megbénította az eljárást, ami miatt a védést el kellett napolni. A második napon pedig Siklós András, a történelemtudományok kandidátusa, a kádári megtorlások idején Szabad György főnöke, felszólalásában polgárinak, nem marxistának minősítette az értekezést és szerzőjét, amivel megkérdőjelezte az egész minősítést, hiszen tudományos fokozatot csak marxista munka szerzőjének lehetett odaítélni (MTAL, Jegyzőkönyv. 1-54; Állásfoglalás).

Az értekezés opponensei, Sőtér István irodalomtörténész, az MTA tagja, az MTA Irodalomtudományi Intézetének főigazgatója, Kovács Endre, a történelemtudományok doktora, az MTA Történettudományi Intézetének tudományos osztályvezetője és Kosáry Domokos, a történelemtudományok kandidátusa, az MTA Történettudományi Intézetének tudományos főmunkatársa voltak. A jelölt tudományos életrajzának ismertetése után az opponensek felolvasták egyértelmủen pozitív opponensi véleményeiket, amit vita követett. Mindhárom opponens kiemelte és nagyra értékelte a monográfia tárgyilagosságát, adatgazdagságát és szakmai színvonalát. Sőtér István Szabad György müvét a Világos utáni bő évtized irodalmi jelenségei és legnagyobb alkotói, Arany János, Madách Imre és Vaj- 
da János költészete szempontjából ezért úttörésként és politikatörténeti vonatkoztatásként üdvözölte. Úgy látta, hogy költészetüket magyarázza, hogy míg 1848 előtt a haladás, a társadalmi kérdések felvetésével lehetett mozgósítani a nemzet, a nemzeti ügy mellett, addig az önkényuralom korában a nemzet, a nemzeti ügy ébrentartásával lehetett fenntartani a haladás, a társadalmi demokratizmus igényét. Kovács Endre arra mutatott rá, hogy a monográfia az 1860-61-es nemzeti ellenállás részletes, a küzdelem teljes spektrumát feltáró korrajzát nyújtja. Tanulsága, hogy a függetlenség iránti helytálláshoz nem társult arányos társadalmi és nemzetiségi program. Nemcsak a hazai politikában, hanem az emigrációban, így Kossuthnál sem. A nemzetiségi kérdés esetében azért, mert a politikusok és a politizáló közvélemény ragaszkodott az ország területi integritásához. Kosáry Domokos dicsérte az értekezés igényességét, anyaggazdagságát, vizsgálati módszereinek sokoldalúságát, magas szakmai színvonalát. Majd a monográfia anyaga alapján arra keresett választ, hogy miért tört meg az ellenállás lendülete. Úgy látta, hogy annak oka a nemesi politikában, a politizáló nagy többségben, s az azt meghatározó társadalmi osztály - politikát determináló - jellegében lelhető fel (Sőtér, 1970; Kovács, 1971; Kosáry, 1969).

\section{AZ ELSŌ NAPI HOZZÁSZÓLÁSOK}

A közönség soraiból elsőként felszólaló Lukács Lajos, a történelemtudományok kandidátusa, Szabad régi ellenfele, a jegyzőkönyv tanúsága szerint ragaszkodott hozzá, hogy írásban elkészített hozzászólását teljes terjedelmében elmondja, s ahhoz reflexiókat is füzzön. Írásos hozzászólása legalább kétszer olyan hosszú volt, mint egy opponensi vélemény. Szerteágazó mondanivalójában mindenekelőtt azt állította, hogy Szabad munkájának címe nem fedi tartalmát. A nemzeti ellenállás ugyanis nem volt forradalom, ám kiegyezés sem volt. Azáltal, hogy a hazai ellenállás nemzeti célokat követett, nem pedig a társadalmi haladásét, a politikai mozgalom jóval ellentmondásosabb volt, mint ahogy Szabad bemutatta. Az emigráció vezetése a felszabadító háború helyett a diplomáciát választotta, emiatt politikája más képet mutat, mint amilyennek Szabad ábrázolta. Mindezek mellett a munka számos forráskritikai kérdést vet fel, mert Szabad összefüggésükből kiragadva értelmezte az egyes dokumentumokat, ugyanis müve elfogult és torzító, mivel nem a marxista forradalomértelmezést követi, nem osztálytartalmukon méri a politikai és társadalmi mozgalmakat, és nem Marx és Engels Kossuth-kritikájára épít. Arra, amely szerint Kossuth mazziniánus kötődését bonapartizmussal váltotta fel. Felrótta Szabadnak, hogy Kossuth nem Garibaldi híve volt, hanem III. Napóleoné (MTAL, Jegyzőkönyv. 1-8., Lukács Lajos hozzászólása 1-26.). Volt, amiben Lukács Lajos - feltehetően - Szabó Ervin Kossuth-képét, a Marx Herr Vogtján alapuló nemesi kiváltságőrző politikus értelmezését kérte számon Szaba- 
don, ám döntően Révai József következetlen forradalmár Kossuth-képét hiányolta. Azt, aminek alapján Kossuthról két szerzőtársával, Mérei Gyulával és Spira Györggyel 1952-ben életrajzot tett közzé. A bizottság és a közönség tagjai közül nyilván többen is tisztában voltak ezzel. A termet 2-kor át kellett adni, amire Mód Aladár felhívta a figyelmet, és ami miatt ismételten figyelmeztette a felszólalót a méltányosságra, az önkorlátozás szükségességére. Szabad György viszont többször is jelezte, hogy érdeklődéssel hallgatja Lukács Lajos hozzászólását. Lukács Lajos azonban nem engedett az elnök kérésének, s korlátlan és korlátozatlan felszólalásával kelepcehelyzetet teremtett. Két kiút kínálkozott ebből: az elnök vagy hatalmi szóval belefojtja a szót, amivel támadhatóvá teszi az eljárást, vagy elnapolja a védést.

A vitában Lukács Lajos után Mód Aladár szólalt fel. Szerinte Szabad differenciálta a birtokos nemességen belüli álláspontokat, Kosáry viszont az osztályérdeket és az osztályt dogmatikusan fogta fel, közvetlenül feleltette meg egymásnak, s így mindkettőt leegyszerüsítette. Hanák Péter úgy látta, hogy a könyv többvariációs fejlődési lehetőséget vázolt fel, amelynek határait szerinte a forradalom megismétlésének és az abszolutisztikus rendszer fennmaradásának lehetetlensége alkották. Egységes nemesség és birtokos osztály helyett inkább annak különböző, egymásnak feszülő irányzatairól beszélhetünk. Mivel a kossuthi program potenciális hívei nem tudtak felülkerekedni, az 1861-es fordulat a kiegyezéshez vezetett. Az érdekegyesítés feltételei ugyanis nem voltak azonosak 1848-ban és 1861-ben, hiszen a feudalizmust 1861-re már felszámolták. Immár a feudális maradványok felszámolása került napirendre, ami viszont új érdekegyesítést kívánt. Hanák Mód Aladárral szemben úgy látta, hogy a 48-asságot a nemzeti önállóság, a demokratikus haladás, az agrárkérdés és a nemzeti kérdés demokratikus megoldása együttesen alkották. A birtokos nemesség viszont - hiszen nem volt nemzeti burzsoázia - nem tudott ennek eleget tenni, ezért lefelé elsáncolta magát, kifelé pedig nem egyezkedett. Egyetértett Kosáryval, hogy amennyiben a magyar birtokos nemes fenn akarta tartani birtokai felett az uralmát, csak az elnyomó hatalomhoz fordulhatott. Lukács Lajosnak viszont igaza van abban, hogy Magyarországon nem volt forradalmi helyzet, és a könyv az emigrációt valóban árnyaltabban mutathatta volna be. Ám tudomásul kell venni, hogy nem mindig esik egybe a legdemokratikusabb a legreálisabbal, a haladás a realitással. A történésznek pedig nem az a feladata, hogy a leghaladóbb realitását bizonyítsa, hanem az, hogy a történelem valóságos ellentmondásait feltárja. Hanák Péter hozzászólása után Sőtér István kért szót. Ő Mód Aladárral értett egyet, Hanákkal pedig vitatkozott. Úgy látta, hogy a Hanák által megfogalmazott maximalista programot az önkényuralom viszonyai között nem lehetett úgy hirdetni, mint 49-ben a debreceni országgyủlésen. Ennek ellenére a magyar irodalom Világos után sok mindent folytatott abból, amit a reformkorban és 48-ban képviselt, ami magyarázatot igényel. Ám azzal, hogy a vita a középnemességre szűkült, s a 
plebejus rétegeket számításon kívül hagyta, kizárta a magyarázat lehetőségét. Lukács Lajost, aki Vajda János röpiratait, az Önbirálatot és a Polgárosodást példamutatóként, s a helyzet lényegét kifejezőként kérte számon, korrigálta: Vajda röpiratait egyáltalán nem lehet politikai programnak tekinteni. Felhívta a figyelmet arra, hogy nemcsak a magyarság került 1861-ben dilemma elé, hanem a nemzetiségek is. Választhattak aközött, hogy a magyar uralkodó osztállyal egyeznek ki, vagy a Monarchiával, s ők az utóbbit választották. A dogmatikus álláspontot ne helyettesítsük önlebecsülö állásponttal - zárta hozzászólását Sőtér István. Ezt követően Mód Aladár elnök a védést másnap reggelig elnapolta (MTAL, Jegyzőkönyv. 8-23.).

\section{A MÁSODIK NAPI HOZZÁSZÓLÁSOK}

A doktori védés másnap, október 28-án délelőtt 10 órakor Kovács Endre felszólalásával folytatódott. A felszólaló tételesen cáfolta Lukács Lajos Kossuth-képét. Azt, hogy Kossuth Mazzini forradalomcsinálását bonapartizmussal váltotta fel, de azt is, hogy az emigráció kossuthiánus és garibaldista táborra oszlott volna meg. Kossuth nem volt bonapartista, s az emigráció nem vált szét kossuthiánus és garibaldista táborra. E téves állítások konstrukciók: az első Marx Herr Vogt címü írásából származik, a második Lukács Lajostól. Marx rossz informátorok hatására alakította ki a maga Kossuth-képét - állította -, amitől ideje lenne elszakadni. Kovács Endre után a közönség soraiból Siklós András, a történelemtudományok kandidátusa jelentkezett szólásra. Ő - az 1957-ben távol lévő tanszékvezető Andics Erzsébet helyettesítője, s így Szabad tanszéki fönöke a kádári megtorlás megindítása idején - jelezte, hogy nem ért a témához, s bár nagyra értékeli a müvet, azt polgári, nem marxista munkának látja, szerzőjét pedig polgári, nem marxista tudósnak. Olyannak idézte Lukács Györgyöt -, aki a síkság (tehát a polgári tudományosság), nem a hegycsúcs (azaz a marxizmus-leninizmus) képviselöje. A végkövetkeztetést mindenki maga vonta le. Azt, hogy bármilyen színvonalú is a monográfia, az értekezés és szerzője nem felel meg a minősítés alapfeltételének. Annak, hogy csak marxista mü és szerző kaphat tudományos fokozatot. A vita egyik hallgatójaként úgy éreztem, hogy a teremben szinte megfagyott a levegő. Siklós András hozzászólását Kosáry Domokosé követte. Igazat adott Sőtér Istvánnak abban, hogy az irodalom megközelítését nem lehet a köznemesség tudatállapotára korlátozni. Ugyanakkor felhívta a figyelmet arra, hogy az 1860/61-es országgyűlés állásfoglalását viszont nem lehet a társadalom tudatállapotára szűkíteni, hiszen az politikai kérdés volt, mégpedig - elsöprő országgyűlési súlya miatt - a nemesi politika kérdése. Azzal kapcsolatban pedig, miszerint álláspontja dogmatikus lenne, vitatkozott Mód Aladárral. Replikája szerint a 
dogmatizmus ugyanis az osztályszemlélet merev alkalmazását, az osztályok, a cselekvések és az ideológia között közvetlen kapcsolat feltételezését és a voluntarizmus múltba vetítését foglalta magában, amihez fel lehetett használni a magyar nacionalizmus egyes elemeit. A múlt illúziók nélküli, tárgyilagos megismerése azonban mentes mindettől. Különböző álláspontokat különböző színvonalon lehet kifejteni. Úgy látta, hogy például Hanák Péter, Lackó Miklós és Ránki György a Magyarország története nyolcadik kötetének koncepcióját előlegező referátuma, amely Gazdaság, társadalom, társadalmi-politikai gondolkodás Magyarországon a kapitalizmus korában címmel jelent meg a következő évben, antedatálva, színvonalas, nem dogmatikus, a múlt reális ismeretére irányul (Hanák et al., 1969). Olyan, amit a részletekre vonatkozó vitathatósága ellenére követendőnek tart. Ö a 19. századi magyar nemesi politikát az egész magyar történelem perspektívájából nézi, míg Szabad máshonnan. Álláspontjuk mindenekelőtt ezért különbözik. Ám Szabad olyan színvonalon fejtette ki álláspontját, amely vitára érdemes. Annak érdekében pedig, hogy a vita kellö színvonalon folyjon, biztosítani kell a vita alapfeltételeit, többek között az egyéni álláspont kifejtésének korlátok közé szorításával - utalt a Lukács Lajos előző napi hozzászólása következtében kialakult helyzet tanulságára (MTAL, Jegyzőkönyv. 24-42.).

Kovács Endre tételesen cáfolta Lukács Lajos merev, dogmatikus, az egyedül igaznak tartott értelmezési keretet számonkérő álláspontját. Siklós András ideológiailag bélyegezte meg a művet és szerzőjét. Kosáry Domokos pedig Mód Aladárral szemben foglalt programszerü állást. Úgy, hogy azzal saját magát az ítélkező szerepébe helyezte.

\section{A VÁLASZ}

Mindezek után kapta meg Szabad György a válaszadás lehetőségét. A kérdésekre és a megjegyzésekre méltóságteljesen, elegánsan, tárgyszerủen válaszolt. Opponenseinek köszönetet mondott, észrevételeikre pedig tételesen válaszolt, ahogy utánuk Lukács Lajosnak is. Sőtér István szerint a mű címe összhangban van a politikai erők belső és külső konfliktusaival, az irodalomban észlelt jelenségekkel és a legnagyobb alkotók fejlődésének dilemmáival. Kovács Endre és Kosáry Domokos viszont fenntartásokat fogalmazott meg a címmel kapcsolatban. Kovács Endre szerint az alternatíva valóban létezett, ám a forradalmi célkitüzések nem mutattak túl 1848-on, legjobb esetben 1849-en, bár 1849 védelme összekapcsolódott továbbfejlesztésének óhajával. Kosáry Domokos elismerte, hogy 1860/61 fordulópont volt az 1848/49-es forradalom és az 1867-es kiegyezés között. A válaszút azonban nem fordulópontra, hanem alternatívára, két lehetőség közötti választásra utal, ami elvben igaz, ám a politikát kézben 
tartó erők szempontjából gyakorlatilag nem az. Szabad szerint 1860 októberében a magyar politikai élet tizenkét év után elöször megnyílt színterein két politikai ajánlat konfrontálódott: a konzervatívok ajánlata, az Októberi Diploma kiegyezési megállapodása és egy széles nemzeti ellenállási koalícióé, amely helyre kívánta állítani az 1848-as forradalmi vívmányokat. A magyar politikai erők túlnyomó többsége elutasította a konzervatív kiegyezési ajánlatot, és az 1848-as forradalmi vívmányok mellett kötelezte el magát. Ám ezzel újabb válaszút elé került. Nevezetesen a forradalmi vívmányok megújítása és kiteljesítése vagy a forradalmi vívmányok csonkítása közötti választás elé. Ez az alternatíva az első lehetőség elhárításával és a második előmozdításával dőlt el. Attól azonban, hogy így dőlt el, maga az alternatíva létezett, valóságos volt, elemei pedig a döntés ellenzőiben és elfogadóiban egyaránt tovább éltek. Kovács Endre Kossuth társadalom- és nemzetiségpolitikájával kapcsolatban hiányolta Szabad bírálatát. Kossuth a társadalmi kérdéseket 48-hoz képest 48-49-ben, majd alkalmi állásfoglalásaiban - a kincstári birtokok zsellérek közötti felosztásától a katonai őrvidéki községek határában fekvő kincstári erdők és legelők a határőrök tulajdonába kerülésén át az iparszabadság megteremtésén keresztül a zsidók egyenjogúsításáig - továbbfejlesztve értelmezte. Ám alapjában - a többi alkotmányos polgári politikushoz hasonlóan - azt remélte, hogy a jó alkotmány keretében megoldódnak a társadalmi problémák is. A nemzetiségi kérdésben Erdéllyel kapcsolatban valóban különbözik a véleményük. Ö úgy látja, hogy Kossuth eljutott az unió vagy az autonómia közötti választásig. Kosáry Domokos szerint a nemesség politikáját 1848-49-ben és utána az a sokk határozta meg, hogy szembekerült a nemzetiségi parasztsággal. A sokkot Szabad is elismeri, ám vitatja a nemesség egységes jellegét. A rendi burokban ugyanis szerinte a nemesség kivételesen tagolt struktúrát mutat, osztályértelemben teljes bomlásban volt. A sokkhatás is ennek megfelelően eltérő módon és intenzitással érte, miként a társadalmilag differenciált nemesség politikai nézetei is differenciáltak voltak.

Szabad György a kiegyezést - Sőtérrel és Kosáryval vitatkozva - nem tekintette sem elvfeladásnak, sem győzelemnek. Ám felhívta a figyelmet, hogy az hogyan ment végbe. Arra, hogy elmozdították a falvak demokratikusan választott vezetőit, felszámolták az önkormányzati szerveket, szétzúzták a polgárság haladó testületeit, a vezető publicisták és lapkiadók megfélemlítésével megrendszabályozták a sajtót, felkutatták és megsemmisítették az ellenállás folytatásával kísérletező szerveket, országgyülési képviselők egész sorát börtönözték be vagy kényszerítették új számüzetésbe, és kézben tartották az 1865-ös országgyülési választásokat. Mindaddig, amíg biztosak lehettek abban, hogy olyan parlament jön létre, amelynek többsége nem a kiegyezés szükségességében, hanem különböző változatai között lát eldönteni valót. Szabad György a vitában elsőként Siklós András hozzászólására válaszolt. Úgy, hogy a bírálóbizottság hatáskörébe utalta 
műve és munkássága jellegének megítélését. Nyilvánvaló volt, hogy Szabad semmilyen formában sem igazodott a besorolási kényszerhez, a merev, osztályszempontú értelmezési kerethez. Ezt követöen tételesen és tárgyszerüen felelt Lukács Lajos kifogásaira és kritikáira, ami a jegyzőkönyvben 12 oldalt tesz ki (MTAL, Jegyzőkönyv. Szabad György válasza. 1-26, 42-54.).

\section{A VITA LEZÁRÁSA, A BIZOTTSÁG ÁLLÁSFOGLALÁSA}

Szabad György válaszát az elnök megköszönte, majd megkérdezte az opponensektől, a bizottság tagjaitól és a hozzászólóktól, hogy elfogadják-e azt. Miután elfogadták, felfüggesztette az ülést, s a bizottság határozathozatalra visszavonult. Ennek eredményeként a héttagú bizottság a fokozat odaítéléséről egyhangúan igennel szavazott. A védés két napon át, összesen tíz órán keresztül tartott. A doktori értekezés vitájának jelentőségét mutatja, hogy az arról készült gyorsírói jegyzőkönyvet Tóth Béla, a Tudományos Minősítő Bizottság titkárságának vezetője elküldte Nagy Miklósnak, a Magyar Szocialista Munkáspárt Központi Bizottsága Tudományos, Közoktatási és Kulturális Osztálya alosztályvezetőjének (MTAL, Jegyzőkönyv; Állásfoglalás doktori fokozat ügyében; Nagy Miklós levele Tóth Bélának).

\section{ÉRTELMEZŐK ÉS ÉRTELMEZÉSI KERETEK}

Az első napi vitában a felszólalók közül többen a kirakós játék végső megoldását, az indoktrinációt, a besorolást kérték számon. Volt, akinél a besorolás igénye meghatározó volt, de akadt olyan is, aki azzal küszködött, hogy a problémamegoldás igényét össze tudja egyeztetni az indoktrináció merev értelmezési keretével. Ám a rigid álláspontot elfoglaló Lukács Lajostól a sziporkázóan ötletelő Hanák Péteren át - a politikai döntéseket az adottságnak tekintett nemzetközi nagyhatalmi politikára és a társadalmi érdekviszonyokra visszavezető állásfoglalását elegánsan kifejtő - Kosáry Domokosig a sémába illesztés, a visszavezetés, a besorolás, az indoktrináció mủveletének igénye meghatározó súlyú volt. Az értelmezési keretet fejlődési séma, a haladás mintájának követése, az újkori francia politikai fejlödés normatívan felfogott modellje, a teleologikus történelem fejlődésmenetének voluntarista vagy/és determinista változata alkotta. Lukács Lajos és Kosáry Domokos más-más színvonalon, de egyaránt ennek jegyében kifogásolta a monográfia címét és koncepcióját.

A második nap hozzászólásai a besorolás számonkérésétől, a sémára viszszavezetés megkövetelésétől a keret átértelmezésén át az indoktrinációs interpretációs keret dekonstruálásáig terjedtek. Siklós András korántsem azok 
közé tartozott, akik segítettek abban, hogy ki-ki kiszabadulhasson a Prokrusztész-ágyból. Éppen ellenkezőleg: a pártállami ideológiát kérte számon. Akkor, amikor kijelentette, hogy a tárgyalt mủ és szerzője nem marxista, amivel az ellenség bélyegét sütötte az értekezésre és írójára. Kovács Endre tételesen cáfolta Lukács Lajos mércéjét, Marx Herr Vogtjának Kossuth-képét és Lukács Lajos konstrukcióját, az emigráció kettéosztását kossuthiánusokra és garibaldistákra. Ezzel pedig a tudományos problémamegoldást választotta az értelmezési keretre visszavezetés, a redukcionizmus, a nagy kirakós játék végső megoldásába besorolás helyett. Kosáry Domokos viszont paradigmatikusan értelmezte át a dogmatizmust: az immár a nacionalista, későbbi kifejezéssel a „nemzeti kommunista" álláspont/beállítottság szinonimája lett. Szemben a nemzeti illúziókkal leszámoló realista önismeret marxista tudományosságával. Azzal, aminek képviseletére maga nyújtott példát. Azáltal, ahogy számon kérte az osztálymeghatározottságot.

Szabad válaszában elkerülte az osztályérdekre visszavezetés redukcionista eljárását, s amikor Kosáry azt számon kérte rajta, elhatárolódott mind attól, mind a determinista sémától. Érzékeltük, hogy korántsem Szabó Ervin, Révai József vagy Molnár Erik álláspontját foglalta el, hanem a jogaiba visszahelyezett problémafeltárást és problémamegoldást, a történész szakszerüségét és a történelem alternativitását képviselte. Ezt pedig a nemzeti liberális pozitivista értelmezési keret, a nomád életformától a letelepült, városi, civilizált életmódig ívelő, a civilizációs haladással azonosított nemzetállami fejlődés értelmezésének társadalomtörténeti alapozottságú megújításával és korszerüsítésével tette. Amivel kitört a marxista kánonból. A vita álláspontjai nem az intézet-egyetem rivalizálása mentén váltak el egymástól. Az opponensek közül Kovács Endre és Kosáry Domokos, a bizottság tagjai közül R. Várkonyi Ágnes és Hanák Péter a Történettudományi Intézet kötelékében dolgozott. Mód Aladár az egyetem tanára volt, de ugyancsak az egyetemen volt állásban Siklós András is.

A vitában az indoktrináció és a tudomány hívei csaptak össze egymással. Az ideológiai számonkérés nyílt, szélsőséges és anakronisztikus változatát Siklós András és Lukács Lajos képviselték, megújítását és korszerüsítését viszont Kosáry Domokos. Rajtuk kívül Mód Aladártól Hanák Péterig szinte mindenki a merev, megcsontosodott értelmezési keret módosítására tett kísérletet. Sőtér István és Kovács Endre pedig kutatási eredményeikkel szembesítették az értelmezési keretet, s azt fontos részleteiben elvetették (vö: Szücs, 1970).

Ebben az időben a természet-, élet- és müszaki tudományok müvelésébe a pártállam ideológiailag már nem szólt bele. A közgazdaságtudomány, a szociológia, a pszichológia, a nyelvészet, az irodalomtudomány és a filozófia területén viszont sokan tették fel maguknak azt a kérdést, hogy amennyiben saját kutatásaik szembekerülnek a marxizmus tételeivel, melyiket válasszák a kettö közül. Voltak, akik azt is meg merték kérdezni maguktól és egymástól, hogy egyáltalán, a marxiz- 
mus mennyire teszi lehetővé az elmélyült, komoly kutatásokat és tudományos magyarázatukat. A filozófiában többen is végigjárták azt a hosszú utat, amelyen Sztálint Leninnel, Lenint Marxszal és Engelsszel, Engelst Marxszal, Marxot a fiatal Marxszal, a fiatal Marxot pedig Marx intencióival helyettesítették. Ám olyanok is akadtak, akik elég elmélyültek, elszántak és bátrak voltak ahhoz, hogy ezen is túl tudjanak lépni.

\section{VISSZAEMLÉKEZÉS}

Szabad György védésére huszonkét év múlva így emlékezett vissza: „A Forradalom és kiegyezés válaszútján a kiegyezés centenáriumán, 1967. május végén látott napvilágot, de szinte visszhangtalan maradt. Mint ahogy a Történettudományi Intézet egyik munkatársa fogalmazott: megjelent a könyv, sokan elolvastuk, de »még várjuk, mi legyen a véleményünk róla«. Terjedelmes is volt, sok volt a bizonyító anyag benne. Viták kereszttüzébe került, de biztatást is kaptam. Egyik tanszéki kollégám, majd Andics Erzsébet is azt tanácsolta, hogy ezt a munkámat feltétlenül nyújtsam be nagydoktori disszertációként. A nagydoktori benyújtásával nem siettem, csak két évre rá következett vitája. Három bírálója közül ketten rendkívül pozitív véleményt írtak róla. Az egyik lektor Kovács Endre volt, a másik Sőtér István, aki külön tanulmányt is publikált a munka egyik részletkérdéséről. Szerinte a Madách-értelmezés szempontjából művem revelációt jelent, mert jól helyezi el a madáchi életművet a korszak viszonyai között, és megmagyarázza, hogy Madách nem outsiderként írta azt, amit írt, hanem egy valós történelmi és politikai vonulatot fejezett ki vele. A harmadik bíráló Kosáry Domokos volt, aki a szakmai elismerését aggodalmaival társította. Szerinte könyvem a kossuthiánus, nacionalista irányzat feltámasztására tesz kísérletet, és alkalmas a dzsentri idealizálására. Az 1969 nyarán/!/ lezajlott nagydoktori vita rendkívül eltért az akadémiai viták szokásos menetétől. Egyik vitapartnerem annak a Kossuthnak a felmutatásával vádolt, aki szembekerül Marxékkal, a garibaldistákkal, helyettük pedig Cavourral és más úri cselszövőkkel szövetkezik. Aki egy jól fésült nemzetiségi politika látszata mögött, titkon, tulajdonképpen a magyar hegemóniát akarja feltámasztani a Dunai Szövetség köntösében. E gondolatnak, íme, most én vagyok a felmagasztalója... Majd felállt az a személy, aki engem már '56 után minősített, s aki Andics távollétében a tanszéket hajdan vezette. Utalt Lukács György Thomas Mannról alkotott véleményére: nagy elefánt, aki a síkságon áll, s nem a marxizmus hegykoszorúján. Ez még sokkal fokozottabban elmondható rólam is. Nem mondta ki, de érzékeltette, én még nagy elefánt sem vagyok - viszont távol állok attól, amit a marxizmus megkövetel. Ez egész szemléletemet jellemzi, számomra a 19. században nem Marx, hanem Kossuth az irányadó. Romantika, naciona- 
lizmus, dzsentriimádat stb. A bírálóbizottságra hagytam, hogy a világnézeti kérdésben véleményt alkosson, a szakmai kérdésekre viszont alapos válaszokat adtam. A vita két napig tartott. Ez egyedülálló volt a minősítések történetében. Végül a bizottság nagy többséggel megszavazta disszertációmra a nagydoktori fokozatot." (Szabad, 2017, 99-101.) Szabad György visszaemlékezésében a vita datálása és néhány részlet pontatlan volt, s a Kosáryval folytatott későbbi vitákat visszavetítette Kosáry opponensi véleményére. Ám a védésen elhangzott vitának és az arra adott válaszának számára kiemelt jelentősége volt. Olyan, amilyet a védés jegyzőkönyvéből láthattunk.

\section{KITEKINTÉS}

Szabad György 1945-ben programnevet választott, amikor Schwartz Györgyről Szabad György névre magyarosította a nevét. Ezután, nyilván öntudatlanul - amennyiben Stephen B. Karpman drámaháromszög értelmezését alkalmazzuk - a traumatikus szerepek közül az áldozat és az elkövető szerepeivel szemben a megmentő szerepét választotta. Azt, ami maga is traumatizált szerepkör.

Történetíróként és tanárként olvasói, hallgatói, tanítványai és kollégái számára olyan mondanivalót fejtett ki, amely alapjában különbözött a konzervatív és a kommunista értelmezésektől. Egymásra vonatkoztatta a liberális demokrácia és a patriotizmus, a szabadságjogok, a hatalommegosztás és a függetlenség vívmányait. Az „illúziók váltógazdaságával” szemben tertium daturt, nemzeti liberális ellenkánont képviselt.

\section{IRODALOM}

Hanák P. - Lackó M. - Ránki Gy. (1969): Gazdaság, társadalom, társadalmi-politikai gondolkodás Magyarországon a kapitalizmus korában. Történelmi Szemle, 3-4, 283-336.

Karpman, S. B (1968): Fairy Tales and Script Drama Analysis. Transactional Analysis Bulletin, 26, 7, 39-43. https://www.karpmandramatriangle.com/pdf/DramaTriangle.pdf

Karpman, S. B. (1972): Eric Berne Memorial Scientific Award Lecture. https://www.karpmandramatriangle.com/pdf/AwardSpeech.pdf

Kosáry D. (1969): Szabadságharc és kiegyezés között. Reflexiók egy témához. Történelmi Szemle, 3-4, 337-344. https:/tti.btk.mta.hu/images/kiadvanyok/folyoiratok/tsz/tsz1969_3-4/kosary.pdf

Kovács E. (1971): A történelem válaszútján. MTA II. Osztályának Közleményei, 1-2, 91-102.

Sőtér I. (1970): A történelem dilemmái. Kritika, 1, 17-22. http://real-j.mtak.hu/5368/1/Kritika_1970.pdf

Szabad Gy. (2017): Aradtól az Országgyülésig. Pavlovits Miklós interjúja Szabad Györggyel 1991-1992. (Szakmai szempontból ellenőrizte és a jegyzeteket készítette Csorba L.) (Tények és tanúk) Budapest: Magvető Kiadó

Szücs J. (1970): A nemzet historikuma és a történetszemlélet nemzeti látószöge. Hozzászólás egy vitához. Budapest, Akadémiai Kiadó 


\section{Források}

Történelemtudományi Szakbizottság (1969): Állásfoglalás doktori fokozat ügyében. Budapest, 1969. dec. 5.

Jegyzőkönyv a bíráló bizottság zárt üléséről, Budapest, 1969. október 27/28.

Magyar Tudományos Akadémia, Levéltár. Jegyzőkönyv Szabad György „Forradalom és kiegyezés válaszútján 1860-61" címü doktori értekezésének 1969. október 27-28-án megtartott megvédéséröl. MTA TMB 180/3, TMB-145-088/1969.

Nagy Miklós levele Tóth Bélának, Budapest, 1969. december 19. MTA TMB Tu/1230/2. 